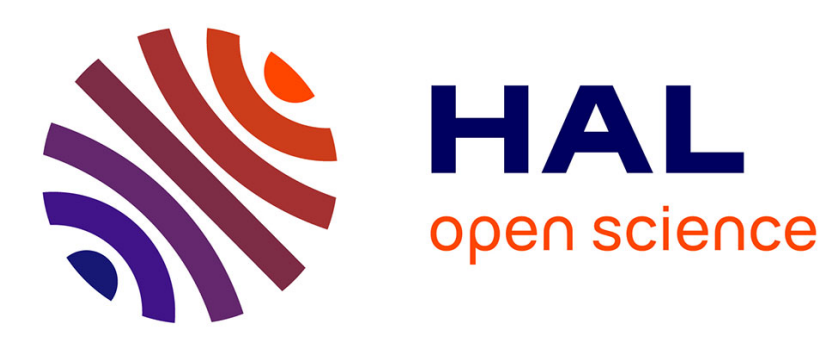

\title{
Satiating effects of protein but not carbohydrate consumed in a between-meal beverage context.
}

\author{
Emma J. Bertenshaw, Anne Lluch, Martin Yeomans
}

\section{To cite this version:}

Emma J. Bertenshaw, Anne Lluch, Martin Yeomans. Satiating effects of protein but not carbohydrate consumed in a between-meal beverage context.. Physiology \& behavior, 2008. hal-00324659

\section{HAL Id: hal-00324659 \\ https://hal.science/hal-00324659}

Submitted on 25 Sep 2008

HAL is a multi-disciplinary open access archive for the deposit and dissemination of scientific research documents, whether they are published or not. The documents may come from teaching and research institutions in France or abroad, or from public or private research centers.
L'archive ouverte pluridisciplinaire HAL, est destinée au dépôt et à la diffusion de documents scientifiques de niveau recherche, publiés ou non, émanant des établissements d'enseignement et de recherche français ou étrangers, des laboratoires publics ou privés. 


\section{${ }^{*}$ Manuscript}

Satiating effects of protein but not carbohydrate consumed in a between-meal beverage context.

Emma J Bertenshaw ${ }^{1}$, Anne Lluch ${ }^{2}$ and Martin R Yeomans ${ }^{1}$

${ }^{1}$ Department of Psychology, University of Sussex, Brighton, UK BN1 9QH.

${ }^{2}$ Danone Research, RD 128, 91767 Palaiseau Cedex, France

\section{Address Correspondence to:}

Emma Bertenshaw

Department of Psychology

University of Sussex

Brighton

BN1 9QH, UK

Tel: +44 1273876561

Fax: +44 1273678058

Email: ejb27@sussex.ac.uk 


\section{ABSTRACT}

Previous research has suggested that protein is the most satiating macronutrient; however some experiments have found no difference in satiating efficiency of protein and carbohydrate during short intervals after consumption. There is also evidence that the satiating effects of carbohydrate are minimal when in a beverage rather than solid context. To evaluate whether protein-based satiety was evident in a drink context, and clarify further effects of preload time on satiety, the present study compared iso-energetic dairy fruit drink preloads $(\sim 1250 \mathrm{KJ})$, differing in macronutrient composition and consumed at two time intervals in the morning. Using a counterbalanced within subjects design, 18 unrestrained lean male volunteers consumed $300 \mathrm{ml}$ of carbohydrate-enriched (CHO), protein-enriched and low energy control (327KJ) dairy fruit drinks, 120 minutes and 30 minutes before an ad libitum lunch. Significantly less energy was consumed at lunch after the protein $(3234 \mathrm{KJ})$ compared to the control $(3468 \mathrm{KJ}, \mathrm{p}<0.05)$ and $\mathrm{CHO}$ preloads $(3588 \mathrm{KJ}, \mathrm{p}<0.05)$. However, this was not sufficient to show complete energy compensation. Preload time of consumption did not impact upon any measures. Only satiety ratings at the beginning of lunch varied significantly by preload type, reflecting differences in test meal intake. These findings are consistent with previous research that protein is more satiating than carbohydrate. The roles of sensory and hedonic characteristics are discussed.

\section{KEY WORDS}

\section{PROTEIN FOOD INTAKE SATIETY CARBOHYDRATE}

BEVERAGE 


\section{Introduction}

Beverages may evoke a weaker compensatory dietary response than solids [1,2] and be a contributing factor to rising obesity levels by promoting a state of positive energy balance [3] . This prevailing view is supported by preload studies in which carbohydrate beverages fail to reduce subsequent intake to the same degree as solids [2,4-7], questioning the generalizability of these findings to mixed composition beverages.

Altering the macronutrient composition of a beverage might improve satiety value. Protein is commonly believed to be the most satiating macronutrient. Protein has a faster oxidization rate than carbohydrates and stimulates greater diet-induced thermogenesis (DIT) which has been related to enhanced satiety [8,9]. Preload studies with solid foods report increased satiety following protein relative to carbohydrate using measures of subsequent intake [10-12], subjective satiety [13,14] or both [15-17]. But not all preload studies confirm differences in intake or motivation measures between protein and carbohydrate [18]. Discrepancies in preload experimental outcomes may depend on preload time interval and volume [19], protein source [20], carbohydrate type (e.g. starch/sugar; high/ low glycemic index) [21] and composition among other factors [22].

A change in the post-ingestive satiety value of macronutrients over time may account for the influence of preload delay upon experimental outcomes. For example, the relative subjective satiating effect of protein may improve over time, while the satiating efficiency of $\mathrm{CHO}$ is more short lived (<60 minutes) [13]. At least for some CHOs, energy adjustment becomes less precise as preload time interval increases up to 120 , or 180 minutes $[23,24]$, but it is unclear whether this rule applies for protein. Few studies have directly compared energy adjustment to both protein and carbohydrate preloads as a function of preload time interval. It is possible that energy adjustment following protein and $\mathrm{CHO}$ is similar early after consumption, but dissociates after time $(>120$ minutes) with protein becoming more proficient [22]. 
The satiating efficiency of protein may also be less when consumed in a drink context [1]. Previous research suggests protein does not influence appetite differently from $\mathrm{CHO}$ when consumed in meal-size portions (e.g. $1680 \mathrm{KJ} / 500 \mathrm{ml})$ at long time intervals ( 27]. However, these findings may reflect methodological limitations such as measuring subsequent intake with food diaries [25], failing to measure intake [25,26], or using relatively low levels of protein (e.g. milk, approximately 33\% energy from protein) [27]. Other evidence suggests protein preloads do attenuate overall hunger more than $\mathrm{CHO}$ alongside more accurate 24-hour energy compensation [28]. Further to this, when consumed in larger quantities (e.g 1 litre), mixed composition high protein loads (40\% and $72 \%$ energy from protein) decreased postprandial hunger and subsequent intake more than a maltodextrin preload at a test meal over 4 hours later [29].

Generally, the literature regarding smaller snack sized beverages (in energy and volume) has been more consistent in establishing differences in energy compensation and subjective appetite between macronutrients at shorter preload delays. This is supported by the observation that caloric beverages may be more effective at eliciting energy compensation at very short time intervals before a test meal [19]. Increasing the protein content of a preload (approx 900KJ) consumed 60 minutes prior to a meal proportionally reduced subsequent intake in two studies [20,30]. There is also evidence that preloads containing low concentrations of protein suppressed hunger more than CHO loads, without a corresponding change in subsequent intake 90 and 30 minutes later [31,32]. However, these studies the test preloads were not matched in characteristics such as viscosity, which critical to the findings [33]. Therefore it is unclear whether moderately increasing protein co an effective strategy to improve the short-term satiety profile of a drink, and to what exten facilitated by the impact of protein on sensory factors rather than post-ingestive effects. Th present a lack of data to allow a comparison of effects of nutrient infusions with oral preload humans [34]. Furthermore, the proposed short term satiating effects of beverages appears with a longer term satiety profile of protein. 
In this study we compared appetitive responses (hunger \& fullness and subsequent intake) to $\mathrm{CHO}$ and protein-enriched drinks administered at 30 minutes and also 120 minutes prior to lunch. This design allowed us to test the hypothesis that protein improves satiety value of a beverage. A secondary aim was to observe if the relative satiating efficiency of protein and $\mathrm{CHO}$ changes with preload time interval, specifically by impacting energy adjustment. Since as noted above, whether the apparent ability of protein to enhance satiety in other studies can be attributed to post-ingestive effects, sensory effects or both remains unclear. However, fully disguising the addition of protein to foods is difficult, and has largely been ignored in many previous studies. To assess for such effects here, products were developed which attempted to match flavours between the different conditions, while sensory and hedonic ratings of the drinks were recorded throughout the present study to test whether effects of protein on satiety corresponded with any subtle sensory differences.

\section{Method}

Design

A counterbalanced single blind within-subjects design, with each participant attending six test sessions in total over a three week period with a minimum of two days between each session. Three test drinks (control, $\mathrm{CHO}$ and protein) were administered at two time intervals of 120 minutes and 30 minutes before the ad libitum test meal. The study was approved by Sussex University Ethics Committee.

\section{Participants}

Participants were recruited from a volunteer database at University of Sussex, and gave informed consent to take part in a study of "Food and Mood". Thirty three male participants attended screening sessions to assess eligibility and a total of 20 participants fulfilled the criteria and attended the test sessions. Selection criteria were males aged $18-34$ years $(23.0 \pm 0.8)$ with a BMI 
of $18-25(22.6 \pm 0.4)$. Participants were required to be non smokers who were not taking any prescribed medication, who regularly consumed breakfast and were unrestrained (defined as a score of $<9$ on the Three Factor Eating Questionnaire: tested sample $3.3 \pm 0.6$ ). In addition, participants completed taste tests of the drinks prior to the experiment. Potential participants who expressed disliking for any of the drinks (defined as $<20$ on a 100 linear scale) were excluded. Two participants were unable to complete the study due to illness (common cold and mumps) and their data were excluded.

\section{Procedure}

Each participant was assigned breakfast, mid morning, pre lunch and lunch consistent appointment times held in the Psychopharmacology Unit at Sussex University. On each test day participants were instructed to consume only water from $11 \mathrm{pm}$ the preceding evening. Breakfast was served in the lab between $8.30-9.45$ and comprised a standard portion of cornflakes, milk and orange juice (total $1694 \mathrm{KJ}$ ). After breakfast, a $500 \mathrm{ml}$ bottle of water was provided for refreshment throughout the test morning and collected before the lunch session began. Participants were able to leave the laboratory after breakfast and returned twice more for the preload appointments. Preload 1 at mid morning was 120 minutes prior to lunch (10.30-11.45am), preload 2, 30 minutes prior to lunch (12.00-1.45pm). To control for expectations about the time of test drink consumption, participants received only one test drink per day, and a placebo drink during the other preload appointment. After completion of the second preload appointment, the water bottles were collected and afterwards participants retired to the waiting room for a short interval before lunch. Served at 12.30-2.15pm, the ad libitum test meal was pasta (Fusilli, Sainsbury's brand) in a commercially produced tomato sauce ("Napoletana sauce", Sainsbury's brand). The combined pasta and sauce had an Energy Density of $4.77 \mathrm{KJ} / \mathrm{g}$ (13.2\% energy protein; $73.4 \%$ energy carbohydrate; $13.4 \%$ fat $)$ and was served on a large pasta dish at a temperature of $60-65{ }^{\circ} \mathrm{C}$.

The order of presentation of preload conditions was randomised for each subject, using a code provided by Danone Research. Individual randomisation envelopes were also sent by Danone 
Research.

Preloads

All three test drinks were administered at two different times (120 minutes vs 30 minutes) before the test meal. Preloads were 1) Control: a low-energy apricot and peach fruit drink (brand Danao® light, Danone), 2) CHO enriched drink: a higher energy version of the apricot and peach control drink (brand Danao®, Danone) enriched with maltodextrin (food grade) comprising 98\% energy from $\mathrm{CHO}$ and 3) Protein enriched drink: a higher energy version of the apricot and peach control drink (brand Danao ${ }^{\circledR}$, Danone) enriched with whey protein isolate (NZMP 8899), fromage-frais (brand Taillefine ${ }^{\circledR}$, Danone) and sugar, containing 50\% energy from protein. All three test drinks were provided by Danone Research for the purpose of this study (see Table 1). The fourth drink was used as a placebo, and was a low-energy flavoured water (Sainsburys' Still Orange and Mango flavoured drink, $0.13 \mathrm{KJ} / \mathrm{ml}$ ). Drinks were presented in covered polystyrene beakers with a straw and the preload time interval began as soon as the drink was administered. Participants were instructed to consume all of the disguised drink (volume of $300 \mathrm{ml}$ ) within 10 minutes.

\section{Measures}

Data was collected using the Sussex Ingestion Pattern Monitor (SIPM), a computer-based system modified from the Universal Eating Monitor [35] for measuring food intake and recording rated appetite [36]. Appetite and mood ratings were recorded by moving a curser along a 500pt linear scale throughout the study. Questions appeared in the format of: "How <word> do you feel?" along a linear scale end-anchored with "not at all" and "extremely", with polarity of the rating randomised to minimise carry-over effects across ratings. Before and after each preload and meal, participants completed 10 motivational and mood ratings: hunger, fullness, thirst, clear headed, happy, friendly, jittery, nauseous, energetic, relaxed. Sensory ratings appeared as "How $<$ word $>$ is the drink?" (familiar, sweet, pleasant, sour, bitter, creamy, fruity, refreshing) and were obtained at each preload 
session after tasting and then consuming test and placebo drinks. Each set of ratings was presented in a random order.

The SIPM measured intake throughout the meal by the use of a disguised electronic balance (Sartorius BP 4100-S, Sartorius, Goettingen, Germany) fitted into the desktop, and connected to an Apple Macintosh G3 computer, with the balance surface obscured by a placemat. The system was custom programmed using FutureBasic (Staz Software) to read the balance weight on stability to $0.1 \mathrm{~g}$ accuracy during the test meal. At the start of the lunch session a $500 \mathrm{~g}$ plate of pasta was placed on the balance and the experimenter left the cubicle. The computer instructions were to "Eat as much as you like". During the meal, the computer interrupted participants after the first stable balance reading in excess of $50 \mathrm{~g}$ since the last interrupt, and the participant completed on-line ratings of thirst, hunger, fullness and pleasantness of the food. A separate side plate was provided to place cutlery during these intervals so that the weight of cutlery did not interfere with the weighing process. The SIPM system also prompted participants to call the experimenter for a refill after the sixth interruption to their meal, by which time $300-400 \mathrm{~g}$ had been consumed. This ensured that participants could not use the empty bowl as an external cue to end their meal. This process was repeated until the participants indicated that they had "finished" their meal and no longer wished to eat. Participants also provided sensory ratings of the test meal (creamy, strong, salty, pleasant), after eating samples at the beginning and end of lunch.

\section{Debriefing}

At the end of the study, participants completed a questionnaire about their awareness of the experimental objectives. After responding to the questions: "what was the purpose of the study?" and "what differences did you notice between the drinks?", each preload was re-presented in covered beakers. Participants tasted the drinks and were asked: "If you drank $300 \mathrm{ml}$ (a cup full) of each of these drinks, how full would you feel?" Answers were given on pen and paper 160mm (VAS scales end-anchored "extremely full" to "not at all full.") Participants were also given a 
description of the energy/macronutrient contents of the three test drinks and were asked to match these descriptions to the drinks. These questions served to identify whether participants were able to make predictions about how satisfying a drink would be based on sensory qualities alone.

\section{Data analysis}

Repeated measures two way ANOVAs were conducted on intake data, motivational and sensory ratings. The two main variables were preload Type (protein, $\mathrm{CHO}$ or control) and preload Delay (consumption 120 minutes or 30 minutes before the test meal). To examine effects of preloads on intake, both amount consumed $(\mathrm{g})$ at the test meal and total energy intake (test meal + preload energy + breakfast) were analysed. To test for sensory and hedonic differences between the three test preloads and evaluations of the test meal, Type and Delay were main factors, with the addition of pre-post Taste (ratings taken at start or end of drink/meal).

Hunger, thirst and fullness ratings were recorded at six key points across the day. Data were included before and after both preloads and lunch $(3 \times 2 \times 6)$, and separately by virtue of preload Delay to isolate changes before and after preloads. For microstructural data, statistical outliers were removed. The relationship between rated appetite (hunger and fullness) and actual food intake within the test meal was assessed by determining individual best-fit quadratic functions for each subject's data and then contrasting the three coefficients from these best-fit functions between preload conditions as previously described [37]. The components of the equations were analyzed (y intercept, linear and quadratic) using ANOVA. Maximum hunger and minimum fullness ratings expressed during the meal were also analyzed across conditions. To describe relationships between sensory, motivational and intake data, average scores were created and Spearman Rho correlations were conducted as these variables violated assumptions of normality. Where assumptions of sphericity were violated, Greenhouse Geisser values were used and Bonferonni post hoc tests conducted. Otherwise, within-subjects contrasts were used to test specific predictions. Complete data (including ratings) were obtained for 16 subjects and intake data for 18 subjects. The design 
was incompletely counterbalanced due to 2 subjects dropping out of the study. All available data subsets were included in the analyses. All analyses were conducted using SPSS11.0 running on Macintosh computers.

\section{Results}

\section{Test meal intake}

Test meal intake (Figure 1 ) was altered significantly by Type $[\mathrm{F}(2,34)=4.32, \mathrm{p}<0.05]$, with less food consumed following the protein preload compared to $\mathrm{CHO}[\mathrm{F}(1,17)=6.70, \mathrm{p}<0.05]$ and control $[\mathrm{F}(1,17)=5.83, \mathrm{p}<0.05]$ preloads. The $\mathrm{CHO}$ preload did not reduce intake compared to the control $[F(1,17)=0.89 \mathrm{p}>0.05]$. Preload Delay did not affect amount consumed $[\mathrm{F}(1,17)=1.21$, $\mathrm{p}>0.05]$ and there were no significant interactions between Type and Delay $[\mathrm{F}(2,34)=1.70$, $\mathrm{p}>0.05]$.

To test whether changes in test meal intake compensated for the additional energy in the protein and CHO preloads, total energy intakes were contrasted (Table 2), and these data varied according to Type $[\mathrm{F}(2,34)=37.52, \mathrm{p}<0.0005]$. Total caloric intake was significantly higher $(+710 \mathrm{KJ})$ on the days the protein preload was consumed compared to control $[\mathrm{F}(1,17)=53.37, \mathrm{p}<0.0005]$. $\mathrm{CHO}$ also lead to higher overall energy intake compared to control $(+1045 \mathrm{KJ})[\mathrm{F}(1,17)=67.22, \mathrm{p}<0.0005]$, and protein $(+334 \mathrm{KJ})[\mathrm{F}(1,17)=5.54, \mathrm{p}<0.05]$. Effects of Delay $[\mathrm{F}(1,17)=1.21, \mathrm{p}>0.05]$ and the interaction between Delay and Type $[\mathrm{F}(2,34)=1.70, \mathrm{p}>0.05]$ were not significant.

\section{Ratings of hunger and fullness}

Hunger and fullness after breakfast did not differ significantly across the conditions and were not included in subsequent analyses. The drinks did not produce differences in subjective hunger or fullness throughout the morning (Figures $3 a \& 3 b$ ). As expected, hunger ratings changed over Time 
$[F(2.7,39.9)=76.37, \mathrm{p}<0.0005]$, and this effect also depended on the Delay between the test preload and lunch (interaction between Delay and Time, $[\mathrm{F}(5,75)=3.07, \mathrm{p}<0.05]$. Repeated contrasts of this interaction showed no significant differences between ratings and the prior time interval. As a trend, consuming a test drink in the morning reduced subsequent hunger compared to days when the flavoured water was consumed at this time, but after the second preload of the day, hunger ratings were similar regardless of when the energy load was consumed. Neither the main effect $[F(2,30)=0.11, p>0.05]$ nor any interactions involving Type were significant, indicating no clear changes in rated hunger between preload conditions. Similarly, for fullness, overall ratings did not vary by Type $[F(1.3,19.8)=0.11, p>0.05]$ or Delay $[F(1,15)=0.26, p>0.05]$ and there were no significant interactions involving Type or Delay. As expected, rated fullness varied by Time $[\mathrm{F}(2.8,41.3),=62.93, \mathrm{p}<0.0005]$.

One possible explanation for the apparent lack of effect of Type on rated appetite might be that the inclusion of data before and after the preload reduced the power to pick up subtle effects generated by differences due to the different test preload formulations. To test this, further analyses using two way ANOVA contrasted hunger and fullness before and after the test preload and before lunch separately for Delay 120 and Delay 30 conditions. For hunger in the Delay 120 condition, the only significant effect was for Time of rating $[\mathrm{F}(2,32)=17.86, \mathrm{p}<0.0005]$, but there was a trend for an interaction between Type and Time $[F(2.6,41.1)=2.43, p=0.09]$. Contrasts suggested hunger was initially higher after protein than control (carried over from pre-preload levels) but this relationship had reversed by pre-lunch $[F(1,16)=3.69, \mathrm{p}=0.07$ : see Figure 3]. However, in the Delay 30 condition, although hunger ratings again differed significantly with Time $[\mathrm{F}(2,30)=11.34$, $\mathrm{p}<0.0005]$, no significant main effect of Type $[\mathrm{F}(2,30)=1.79, \mathrm{p}>0.05]$ or interactions were found. For fullness, there was no significant main effect or interactions involving Type at either Delay, but the expected main effect of Time was evident $[120$ minutes: $F(2,32)=10.87$, $p<0.0005 ; 30$ minutes: $F(2,30)=11.38, p<0.0005]$. 


\section{Microstructural analyses of appetite within the test meal}

The outcome of the analyses of hunger and fullness ratings across the test meal are summarised in Table 3. The best-fit quadratic functions relating hunger and fullness ratings to actual intake during the test meal accounted for $90 \%$ of the variance in these ratings. For both hunger and fullness, there were no significant differences between these best-fit components except for the Y-intercept. With the Y-intercept for rated hunger, there was a significant main effect of Type $[F(2,30)=3.85$, $\mathrm{p}<0.05]$, but no significant effects of Delay $[\mathrm{F}(1,15)=0.002, \mathrm{p}>0.05]$ or Type*Delay interaction $[\mathrm{F}(2,30)=0.24, \mathrm{p}>0.05]$. Contrasts revealed a lower $\mathrm{Y}$-intercept for hunger after protein than both control $[\mathrm{F}(1,15)=8.34, \mathrm{p}<0.05]$ and $\mathrm{CHO}$ preloads $[\mathrm{F}(1,15)=5.43, \mathrm{p}<0.05]$. Likewise, Type significantly affected the $Y$-intercept for fullness $[\mathrm{F}(2,30)=3.63, \mathrm{p}<0.05]$, with higher $\mathrm{Y}$-intercept in the protein than $\mathrm{CHO}$ condition $[\mathrm{F}(1,15)=6.40, \mathrm{p}<0.05]$, and similarly in the control condition $[F(1,15)=3.76, p=0.07]$. These results suggest that protein reduced appetite at the start of eating but then did not affect subsequent changes in appetite in response to the food being consumed (see Figure 4). However, it was possible that the large variability in some of the parameters from the best-fit quadratics missed subtle effects of preloads on subsequent stimulation of appetite by the food. As a further test, peak hunger (Table 4), defined as the highest individual hunger rating by each participant at each eating episode, was contrasted between conditions. These data differed significantly between Type $[\mathrm{F}(2,30)=4.35, \mathrm{p}<0.05]$ but effects of Delay $[\mathrm{F}(1,15)=0.28, \mathrm{p}>0.05]$ and the Type*Delay interaction $[\mathrm{F}(2,30)=0.65, \mathrm{p}>0.05]$ was not significant. Peak hunger was lower in the protein than control $[\mathrm{F}(1,15)=6.77, \mathrm{p}<0.05]$ and $\mathrm{CHO}[\mathrm{F}(1,15)=6.60, \mathrm{p}<0.05]$ conditions, in line with differences in intake. Similarly, minimum fullness ratings differed between preload Type $[\mathrm{F}(2,30)=3.85, \mathrm{p}<0.05]$, and were higher following protein than $\mathrm{CHO}[\mathrm{F}(1,15)=$ $8.09, \mathrm{p}<0.05]$ and tended to be higher than in the control $[\mathrm{F}(1,15)=4.12, \mathrm{p}=0.06]$.

\section{Thirst}

In general, increased protein content of diets is associated with increased water intake in rats e.g. [38] while post-ingestive osmotic effects could contribute to the effects of maltodextrin on intake 
[39]. The potential differential effects of Type effects on food intake. Thirst ratings taken at significantly between Type $(\mathrm{F}(2,30)=0.04, \mathrm{p}>0$ with the Time of rating $[F(2.6,40.2)=25.57$, between Delay and Time $[F(3.4,51.1)=3.25, \mathrm{p}<\mathrm{C}$ indicated a larger decline in thirst when the place a test drink $(-45.5)[F(1,15)=5.24, \mathrm{p}<0.05]$. Ove $(\mathrm{r}=0.09)$ of lunch did not correlate with test meal

Nausea

A further potential complication in the interpreta occur if preloads altered feelings of well-being $p$ nausea. As with the appetite ratings, delay conc nausea before and after all preloads and lunch affected significantly by preload Type $[\mathrm{F}(2,32)=$ $\mathrm{p}>0.05]$ or Type*Time interaction $[\mathrm{F}(4.1,66.3)=$ higher ratings of nausea in the protein prelo $(78.516 .5)[F(1,16)=13.96, \mathrm{p}<0.01]$. This may preload (see below) only two hours after breakfast in a state of repletion. This explanation is supported by no significant effect of Type $[F(2,30)=1.01, p>0.05]$, Time or the interactions for nausea ratings in Delay 30 when drinks were consumed shortly before the test meal. Overall, nausea ratings before lunch were not correlated with intake $(r=-0.15, p>0.05)$.

\section{Sensory and Hedonic ratings of the test meal and preloads}

Pleasantness of the test meal was not affected significantly by Type $[\mathrm{F}(2,32)=0.10, \mathrm{p}>0.05]$ or Delay $[\mathrm{F}(1,16)=0.00, \mathrm{p}>0.05]$, but as expected declined from the initial Pre-post Taste test (364.4 \pm 14.5$)$ to the final rating $[325.4 \pm 18.4: F(1,16)=8.57, p<0.01]$. There were marginally 
significant interactions between both Type*Delay*Pre-post Taste $[\mathrm{F}(1.4,22.8)$ pleasantness of the test meal decreased mo Delay 120 condition. Given the large numb A possible complication in studies like this sessions. However an ANOVA comparing suggesting monotony did not adversely affec to session $6[341.7 \quad 15.2: F(1,16)=1.03, p$

Despite attempts to match preloads as pleasantness across Type $[\mathrm{F}(1.4,21.4)=4.5$ $p=0.07]$ but no significant difference of Preinteractions. Overall the control was rated (298.2 35.3), with CHO intermediate (354. Overall, preloads tended to be rated as slight 27.8) than 120 minutes before $(336.323$ $21.3)=15.28, \mathrm{p}<0.0005]$ : protein $(443.7 \pm 13.0)$ was rated creamier than $\mathrm{CHO}(372.6 \pm 11.2$ : $\mathrm{p}<0.0005)$ and control $(298.9 \pm 27.6$ : $\mathrm{p}<0.0005)$. Overall creaminess was also affected by Delay [F $(1,15)=5.61, \mathrm{p}<0.05]$, with preloads rated $22.2( \pm 9.4) \mathrm{pts}$ creamier at the 30 than 120 -minute delay. There was also a complex interaction of Type, Delay and time of rating (Pre-post Taste) with creaminess $[F(1.4,21.6)=4.27, \mathrm{p}<0.05]$, and contrasts suggested this related to the $\mathrm{CHO}$ condition where creaminess decreased by 13 points at the 120 minute delay, and increased by the same at the 30 minute delay. The cause of this effect was unclear. Sweetness differed only by Type $[F(2,30)=$ 11.29, $\mathrm{p}<0.0005]$, with $\mathrm{CHO}(412.2 \pm 9.2)$ rated sweeter than control $(357.3 \pm 18.8)(\mathrm{p}<0.01)$ and protein preloads $(320.6 \pm 22.2: \mathrm{p}<0.01)$. 


\section{The relationship between sensory/hedonic evaluations and subsequent intake}

A key question was whether the reduction in test meal intake after protein could be attributed to post-ingestive effects of protein, or the effects of protein on the sensory qualities of the preloads. To test this, test meal intake was correlated with average sensory, hedonic and appetite ratings. Test meal intake overall was positively correlated with maximum hunger ratings $(r=0.38, p<0.0005)$ and hunger pre lunch $(\mathrm{r}=0.33, \mathrm{p}<0.001)$, but negatively with minimum fullness ratings $(\mathrm{r}=-0.437$, $\mathrm{p}<0.0005)$. Intake was not correlated with preload pleasantness $(\mathrm{r}=0.16, \mathrm{p}>0.05)$, creaminess $(\mathrm{r}=-$ $0.05, \mathrm{p}>0.05)$ or sweetness $(\mathrm{r}=0.11, \mathrm{p}>0.05)$. Pleasantness of the test preload was correlated positively with rated sweetness $(\mathrm{r}=0.33, \mathrm{p}<0.001)$ and correlated negatively with preload creaminess $(-0.22, \mathrm{p}<0.05)$.

\section{Counterbalancing}

Unequal counterbalancing occurred due to two participants failing to complete all six sessions. To check for order effects, intake scores were contrasted between Type with session order as an additional factor, collapsed across Delay conditions (there were insufficient data points to allow inclusion of Delay as a factor in this analysis, and since Delay had no impact on intake in any previous analysis we deemed this to be the best test of order effects possible). Order of session did not significantly effect intake $[\mathrm{F}(1,17)=2.74, \mathrm{p}>0.05]$ nor was there any significant interaction between Type and session order $[\mathrm{F}(2,34)=1.74, \mathrm{p}>0.05]$.

\section{Awareness}

In interpreting the effects of the protein preload on intake, a further consideration was the extent to which beliefs about the satiating nature of each product may have influenced the outcome. At the end of the study, estimated fullness ratings based on the sensory qualities of each drink varied significantly between the three test preloads $[\mathrm{F}(2,34)=10.30), \mathrm{p}<0.0001]$. Participants perceived the protein drink to be more satiating than both the control $[\mathrm{F}(1,17)=19.28, \mathrm{p}<0.0005]$ and $\mathrm{CHO}$ drink $[\mathrm{F}(1,17)=4.61, \mathrm{p}<0.05]$ and $\mathrm{CHO}$ was perceived to be more satiating than the control $[\mathrm{F}$ 
$(1,17)=6.58, \mathrm{p}<0.05]$. On the $160 \mathrm{~mm}$ line scale used, prospective satiety ("If you drank $300 \mathrm{ml}$ (a

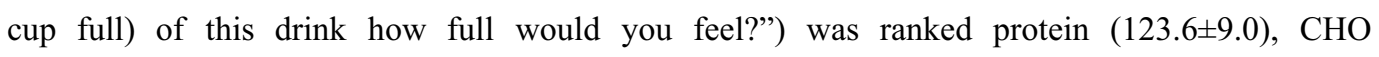
(106.9 \pm 10.2$)$, control $(91.6 \pm 8.4)$. However, when simply asked to match the flavours to the nutrient descriptions, only four participants correctly identified all the drinks, with 14 participants correctly identifying the low energy version compared to only six identifying the $\mathrm{CHO}$ and protein preloads. Thus, it is unlikely participants' satiety beliefs were based on awareness of macronutrient content. 


\section{Discussion}

The main findings of this study were: a) reduced food consumption at a subsequent test meal, along with reduced hunger at both the onset of eating and as peak hunger during the meal, following consumption of a high-energy protein-enriched beverage b) no effect of consuming a high energy CHO beverage on subsequent test meal intake or rated appetite and c) no difference in effects of preloads consumed 120 or 30 minutes prior to the test meal.

Protein reduced intake at lunch by approximately $335 \mathrm{KJ}$ more than $\mathrm{CHO}$ and $234 \mathrm{KJ}$ more than the control overall, therefore the protein-enriched drink led to better energy adjustment than CHO. This small adjustment was not complete: energy compensation and overall energy intake were greater in both high-energy preload conditions compared with when the low energy alternative was consumed. Furthermore, consumption of either high energy drinks at mid-morning did not appear to keep hunger "at bay" until lunch: subjective evaluations of satiety did not capture any differences in experienced appetite. At the start of the test meal, detailed analysis of patterns of change in hunger and satiety, but not crude ratings alone, were affected by the protein preload. Consuming a higher energy drink in place of a low energy drink therefore did not alter measurable time-dependent fluctuations in motivational state prior to lunch. Differences between the two macronutrients did emerge later - at the start and during the meal: subjective satiety measures were all significantly enhanced in the protein conditions corresponding to reduction of intake during the meal.

Primarily then, our results lend some support to the growing body of evidence that, gram for gram protein is more satiating than $\mathrm{CHO}$ [e.g. 16,17]. Previous researchers have suggested a number of possible mechanisms of action of protein to account for this effect, including increased Diet Induced Thermogenesis [9,40], effects of circulating amino acids [41,42] and intestinal signals such as GLP-1 [40,43] and most recently PYY [44] associated with protein intake. 
The reality is likely to involve a complex synergy of physiological signals as well as orosensory, cognitive and conditioned factors. A feature which has not been widely explored is the extent to which subtle sensory cues produced by the presence of protein may either account for protein preload effects themselves, or may interact with post-ingestive cues. Extricating the impact of protein on food flavour from the physiological impact of protein post-ingestion is likely to depend on results in the future from experimental designs using non-oral loads. Animal research findings do suggest there is an immediacy to the effects of protein upon satiety which may not be a direct result of orosensory characteristics such as palatability, but arise from a system of early protein detection and/or postabsorptive factors $[45,46]$. Our data lends support to these findings and indicate that either some form of direct detection of protein is important, or that later post absorptive phases are not as critical as previously thought.

Not withstanding the physiological impact of sensory factors such as viscosity upon satiety factors, e.g. gastric emptying rate, the question remains how cognitively detected sensory differences may impact satiety. Participants made satiety predictions about the drinks in our study, which indicates the existence of cognitive associations between flavour and a satiety consequence. For the protein based drink, the prediction mapped onto the behavioural data - it was the most satiating- for the CHO preload however, this prediction was inaccurate. Prospective satiety measures in the present study were made after participants had twice consumed each preload, and so without ratings collated before and after exposure, it is unclear whether predictions reflected pre-existing beliefs or were influenced by exposure during the study [47].

How might the sensory qualities of preloads impact inter meal satiety? The role of palatability is likely to be complex, as researchers have claimed highly palatable foods are more [48], less [49] and no different in satiating efficiency than less palatable foods [50]. However, in this study, the protein preload was deemed less palatable, but lead to reduced food consumption regardless of the time interval until the meal. If palatability were solely influencing the results, we would predict this 
effect to be significantly more pronounced when the drink was consumed just prior to the meal, which was not the case. Enhanced palatability has also been linked to increased DIT of foods $[51,52]$ which in turn has been related to satiety. This theory would incorrectly predict the CHO beverage to be more satiating than protein in our study. Another theory relates to sweetness. Although we used a $\mathrm{CHO}$ source with minimal sweetness, the $\mathrm{CHO}$ preload was slightly sweeter and consequently, stimulation of appetite by sweetness may have opposed any post-ingestive effects on satiety. Although the stimulatory effects of sweetness have only been postulated for intense sweeteners [53] and again, we might have expected this effect to be greater prior to lunch than earlier. Creaminess may be a noteworthy difference, reflecting principally thickness and smoothness, arguably key properties of perceived fatty foods [54,55]. There is some evidence that preload viscosity may impact subsequent food intake in rats [56,57] but to date only evidence that high viscous fluids can reduce hunger levels in humans, not intake [58].

Matching preloads with different energy densities or macronutrient content is a challenge particularly when working with relatively low energy contents and volumes. Of previous studies in this field, only a few report or measure some sensory and hedonic dimensions $[13,18,25,32]$ or carry out pilot testing beforehand [30,59]. The majority have used different natural meals and drinks or do not specify if any pilot testing has been conducted to sensorily match preloads [10$12,14-17,21,26,27,60,61]$. Of these studies some $[11,12,15,27,60]$ include only a measure of palatability. Consistent reporting of sensory characteristics of preloads is good practise and allows for comparison across the literature.

Another surprising finding of this study was the failure of our $\mathrm{CHO}$ beverage to impact satiety at all. The $\mathrm{CHO}$ beverage tended to reduce intake when consumed 30 minutes prior to lunch compared to 120 , but if anything to increase intake at 120 minutes. Almiron-Roig and colleagues reported that varying the time interval between $\mathrm{CHO}$ solid and liquid preloads (cola and cookies) greatly impacted subsequent intake more so than the physical state of the snack [24]. Two of the main 
differences between Almiron-Roig's work and the current study design was our procedure of administering two drinks each day to mask the test drink, therefore reducing expectation effects, and our choice of lower energy dense drinks. However in the present study, the maltodextrin enriched drink did not facilitate energy adjustment compared to the control at a 30-minute preload delay despite a surplus of $900 \mathrm{KJ}$. This finding also contrasts to research using similar energy dense maltodextrin-enriched soups [39] using a similar preload delay and procedure. Consequently our findings point to the increasing body of research that beverages and soups differ in their satiating properties $[1,5]$.

The trend for greater lunch intake following consumption of a $\mathrm{CHO}$ drink at mid morning relative to the control, suggests nutrient specific stimulatory effects upon appetite. We might explain this pattern by virtue of glycemic response $[62,63]$ through steep alterations in plasma insulin and glucose profiles. Maltodextrin (hydrolysed starch) is a relatively non-sweet polymer with a high rate of absorption, and like glucose it is a high GI food. Such foods might be more satiating than low GI foods $<1 \mathrm{hr}$ before a meal [64] and are associated with increased subsequent intake at longer intervals (e.g. 135 minutes) [65]. However we did not find a significant reduction in lunch intake at 30 minutes Delay and cannot infer that a rebound effect of hypoglycaemia occurred.

Two additional possible confounds of effects of protein were tested here, but have been largely ignored in previous studies. Firstly, the known ability of high protein foods to increase fluid intake [38] could potentially have lead to competition between hunger and thirst, and resulted in reduced eating as a consequence. However, no differential effects of preloads on thirst were evident. Secondly, the ingestion of the two enriched preloads may have produced unpleasant gastric effects which in turn could have impacted on eating. Although there was some evidence for small increases in rated nausea following consumption of the protein preload 120 minutes prior to test, this was not seen 30 minutes prior to test. Since appetite at lunch was similar regardless of preload 
times, it is unlikely that reduced intake following protein was a consequence of these small changes in induced nausea.

To summarize, these data suggest that the general conclusion in the literature that nutrients consumed as beverages have little impact on satiety, depends on the macronutrient composition of the drink. Thus our results support the hypothesis that some types of $\mathrm{CHO}$ caloric drinks fail to induce satiety and energy adjustment. However an iso-energetic drink enriched in protein $(12.5 \mathrm{~g} / 100 \mathrm{ml}$ of protein with about half of the energy from protein) lead to reduced hunger and better energy adjustment at a subsequent test meal, suggesting protein retains some ability to satiate even when consumed in beverage format. Further research is required to ascertain whether supplementing $\mathrm{CHO}$ drinks with mixed protein-based drinks is a better option for individuals wanting to consume energy drinks while keeping a good control of their appetite. Such studies might establish if a minimum content of protein composition is required to improve the satiety profile of a drink. In the mean time, choosing a lower calorie drink as a snack might be the optimum choice.

\section{Acknowledgements}

This research was part of a PhD funded by Danone Research. The authors are grateful to Stéphane Doat for designing and supplying the beverages in this study. 


\section{References}

1. Mattes R: Fluid calories and energy balance: The good, the bad, and the uncertain. Physiol Behav 2006;89:66-70.

2. Mattes RD: Dietary Compensation by Humans for Supplemental Energy Provided as Ethanol or Carbohydrate in Fluids. Physiol Behav 1996;59:179-187.

3. Ludwig DS, Peterson KE, Gortmaker SL: Relation between consumption of sugar sweetened drinks and childhood obesity: a prospective, observational analysis. Lancet 2001;357:505-508.

4. DiMeglio DP, Mattes RD: Liquid versus solid carbohydrate: effects on food intake and body weight. Int J Obes Relat Metab Disord 2000;24:794-800.

5. Mattes R: Soup and satiety. Physiol Behav 2005;83:739-747.

6. Bolton RP, Heaton KW, Burroughs LF: The role of dietary fiber in satiety, glucose, and insulin: studies with fruit and fruit juice. Am J Clin Nutr 1981;34:211-217.

7. Haber GB, Heaton KW, Murphy D, Burroughs LF: Depletion and disruption of dietary fibre. Effects on satiety, plasma-glucose, and serum-insulin. Lancet 1977;2:679-682.

8. Halton TL, Hu FB: The effects of high protein diets on thermogenesis, satiety and weight loss: a critical review. J Am Coll Nutr 2004;23:373-385.

9. Westerterp-Plantenga MS, Rolland V, Wilson SA, Westerterp KR: Satiety related to $24 \mathrm{~h}$ diet-induced thermogenesis during high protein/carbohydrate vs high fat diets measured in a respiration chamber. Eur J Clin Nutr 1999;53:495-502.

10. Booth DA, Chase A, Campbell AT: Relative effectiveness of protein in the late stages of appetite suppression in man. Physiol Behav 1970;5:1299-1302.

11. Barkeling B, Rossner S, Bjorvell H: Effects of a high-protein meal (meat) and a highcarbohydrate meal (vegetarian) on satiety measured by automated computerized monitoring of subsequent food intake, motivation to eat and food preferences. Int J Obes 1990;14:743751.

12. Marmonier C, Chapelot D, Louis-Sylvestre J: Effects of macronutrient content and energy density of snacks consumed in a satiety state on the onset of the next meal. Appetite 2000;34:161-168.

13. Fischer K, Colombani PC, Wenk C: Metabolic and cogntive coefficients in the development of hunger sensations after pure macronutrient ingestion in the morning. Appetite 2004;42:49-61.

14. Hill AJ, Blundell J: Macronutrients and Satiety: The Effects of a High-Protein or highCarbohydrate Meal on Subjective Motivation to Eat and Food Preferences. Nutr \& Behav 1986;3:133-144.

15. Poppitt SD, McCormack D, Buffenstein R: Short-term effects of macronutrient preloads on appetite and energy intake in lean women. Physiol Behav 1998;64:279-285.

16. Johnson J, Vickers Z: Effects of flavor and macronutrient composition of food servings on liking, hunger and subsequent intake. Appetite 1993;21:25-39.

17. Porrini M, Crovetti R, Testolin G, Silva S: Evaluation of satiety sensations and food intake after different preloads. Appetite 1995;25:17-30.

18. Raben A, Agerholm-Larsen L, Flint A, Holst JJ, Astrup A: Meals with similar energy densities but rich in protein, fat, carbohydrate, or alcohol have different effects on energy expenditure and substrate metabolism but not on appetite and energy intake. Am J Clin Nutr 2003;77:91-100.

19. Almiron-Roig E, Chen Y, Drewnowski A: Liquid calories and the failure of satiety: how good is the evidence? Obes Rev 2003;4:201-212.

20. Anderson GH, Tecimer SN, Shah D, Zafar TA: Protein source, quantity, and time of consumption determine the effect of proteins on short-term food intake in young men. $\mathrm{J}$ Nutr 2004;134:3011-3015. 
21. Rolls BJ, Hetherington M, Burley VJ: The specificity of satiety: the influence of foods of different macronutrient content on the development of satiety. Physiol Behav 1988;43:145153.

22. Reid M, Hetherington M: Relative effects of carbohydrates and protein on satiety -- a review of methodology. Neurosci Biobehav Rev 1997;21:295-308.

23. Rolls BJ, Kim S, McNelis AL, Fischman MW, Foltin RW, Moran TH: Time course of effects of preloads high in fat or carbohydrate on food intake and hunger ratings in humans. Am J Physiol 1991;260:R756-763.

24. Almiron-Roig E, Flores SY, Drewnowski A: No difference in satiety or in subsequent energy intakes between a beverage and a solid food. Physiol Behav 2004;82:671-677.

25. de Graaf C, Hulshof T, Weststrate JA, Jas P: Short-term effects of different amounts of protein, fats, and carbohydrates on satiety. Am J Clin Nutr 1992;55:33-38.

26. Driver CJ: The effect of meal composition on the degree of satiation following a test meal and possible mechanisms involved. Br J Nutr 1988;60:441-449.

27. Almiron-Roig E, Drewnowski A: Hunger, thirst, and energy intakes following consumption of caloric beverages. Physiol Behav 2003;79:767-773.

28. Westerterp-Plantenga MS, Verwegen CR: The appetizing effect of an aperitif in overweight and normal-weight humans. Am J Clin Nutr 1999;69:205-212.

29. Latner JD, Schwartz M: The effects of a high-carbohydrate, high-protein or balanced lunch upon later food intake and hunger ratings. Appetite 1999;33:119-128.

30. Lambert TC, Hill AJ, Blundell J: Investigating the satiating effect if protein with disguised liquid preloads. Appetite 1989;12:220.

31. Harper A, James A, Flint A, Astrup A: Increased satiety after intake of a chocolate milk drink compared with a carbonated beverage, but no difference in subsequent ad libitum lunch intake. Br J Nutr 2007;97:579-583.

32. Tsuchiya A, Almiron-Roig E, Lluch A, Guyonnet D, Drewnowski A: Higher satiety ratings following yogurt consumption relative to fruit drink or dairy fruit drink. J Am Diet Assoc 2006;106:550-557.

33. Geliebter A: Effects of Equicaloric Loads of Protein, Fat, and Carbohydrate on Food Intake in the Rat and Man. Physiol Behav 1979;22:267-273.

34. French SJ: The effects of specific nutrients on the regulation of feeding behaviour in human subjects. Proc Nutr Soc 1999;58:533-539.

35. Kissileff HR, Klingsberg G, Van Itallie TB: Universal eating monitor for continuous recording of solid or liquid consumption in man. Am J Physiol 1980;238:R14-22.

36. Yeomans MR: Rating changes over the course of meals: what do they tell us about motivation to eat? Neurosci Biobehav Rev 2000;24:249-259.

37. Yeomans MR: Palatability and the micro-structure of feeding in humans: the appetizer effect. Appetite 1996;27:119-133.

38. Fitzsimons TJ, Le Magnen J: Eating as a regulatory control of drinking in the rat. J Comp Physiol Psychol 1969;67:273-283.

39. Yeomans MR, Gray RW, Conyers TH: Maltodextrin preloads reduce food intake without altering the appetiser effect. Physiol Behav 1998;64:501-506.

40. Lejeune MP, Westerterp KR, Adam TC, Luscombe-Marsh ND, Westerterp-Plantenga MS: Ghrelin and glucagon-like peptide 1 concentrations, 24-h satiety, and energy and substrate metabolism during a high-protein diet and measured in a respiration chamber. Am J Clin Nutr 2006;83:89-94.

41. Mellinkoff SM, Frankland M, Boyle D, Greipel M: Relationship between serum amino acid concentration and fluctuations in appetite. J Appl Physiol 1956;8:535-538.

42. Hall WL, Millward DJ, Long SJ, Morgan LM: Casein and whey exert different effects on plasma amino acid profiles, gastrointestinal hormone secretion and appetite. Br J Nutr 2003;89:239-248. 
43. Blom WA, Lluch A, Stafleu A, Vinoy S, Holst JJ, Schaafsma G, Hendriks HF: Effect of a high-protein breakfast on the postprandial ghrelin response. Am J Clin Nutr 2006;83:211220

44. Batterham RL, Heffron H, Kapoor S, Chivers JE, Chandarana K, Herzog H, Le Roux CW, Thomas EL, Bell JD, Withers DJ: Critical role for peptide YY in protein-mediated satiation and body-weight regulation. Cell Metab 2006;4:223-233.

45. L'Heureux-Bouron D, Tome D, Bensaid A, Morens C, Lacroix M, Huneau JF, Fromentin G: Preabsorptive factors are not the main determinants of intake depression induced by a highprotein diet in the rat. Physiol Behav 2004;81:499-504.

46. Bensaid A, Tome D, Gietzen D, Even P, Morens C, Gausseres N, Fromentin G: Protein is more potent than carbohydrate for reducing appetite in rats. Physiol Behav 2002;75:577582.

47. Gibson EL: Learned influences on human food choice and intake: a review. In British Feeding and Drinking Group: 30th Annual Meeting. University of Birmingham, 2006.

48. Warwick ZS, Hall WG, Pappas TN, Schiffman SS: Taste and smell sensations enhance the satiating effect of both a high-carbohydrate and a high-fat meal in humans. Physiol Behav 1993;53:553-563.

49. Hill AJ, Magson LD, Blundell JE: Hunger and palatability: tracking ratings of subjective experience before, during and after the consumption of preferred and less preferred food. Appetite 1984;5:361-371.

50. De Graaf C, De Jong LS, Lambers AC: Palatability affects satiation but not satiety. Physiol Behav 1999;66:681-688.

51. Soucy J, Leblanc J: Protein meals and postprandial thermogenesis. Physiol Behav 1999;65:705-709.

52. LeBlanc J, Brondel L: Role of palatability on meal-induced thermogenesis in human subjects. Am J Physiol 1985;248:E333-336.

53. Rogers PJ, Carlyle JA, Hill AJ, Blundell JE: Uncoupling sweet taste and calories: comparison of the effects of glucose and three intense sweeteners on hunger and food intake. Physiol Behav 1988;43:547-552.

54. Guinard J, Mazzucchelli R: The sensory perception of texture and mouthfeel. Trends in Food Science and Technology 1996;7:213-219.

55. Mela DJ: Sensory assessment of fat content in fluid dairy products. Appetite 1988;10:37-44.

56. Davidson TLS, S.E.: A Pavlovian approach to the problem of obesity. Int J obesity 2004;28:933-935.

57. Davidson TLS, S.E.: Food Viscosity Influences Caloric Intake Compensation and Body Weight in Rats. Obesity Research (2005);13:537-544.

58. Mattes RD, Rothacker D: Beverage viscosity is inversely related to postprandial hunger in humans. Physiol Behav 2001;74:551-557.

59. Teff KL, Young SN, Blundell JE: The effect of protein or carbohydrate breakfasts on subsequent plasma amino acid levels, satiety and nutrient selection in normal males. Pharmacol Biochem Behav 1989;34:829-837.

60. Stubbs RJ, van Wyk MC, Johnstone AM, Harbron CG: Breakfasts high in protein, fat or carbohydrate: effect on within-day appetite and energy balance. Eur J Clin Nutr 1996;50:409-417.

61. Vozzo R, Wittert G, Cocchiaro C, Tan WC, Mudge J, Fraser R, Chapman I: Similar effects of foods high in protein, carbohydrate and fat on subsequent spontaneous food intake in healthy individuals. Appetite 2003;40:101-107.

62. Brand-Miller JC, Holt SH, Pawlak DB, McMillan J: Glycemic index and obesity. Am J Clin Nutr 2002;76:281S-285S.

63. Wolever TM, Miller JB: Sugars and blood glucose control. Am J Clin Nutr 1995;62:212S221S; discussion 221S-227S. 
64. Anderson GH, Catherine NL, Woodend DM, Wolever TM: Inverse association between the effect of carbohydrates on blood glucose and subsequent short-term food intake in young men. Am J Clin Nutr 2002;76:1023-1030.

65. Spitzer L, Rodin J: Effects of fructose and glucose preloads on subsequent food intake. Appetite 1987;8:135-145. 
Table 1. Composition of the test drinks

\begin{tabular}{|c|c|c|c|}
\hline & Low energy control & $\mathrm{CHO}$ enriched & Protein enriched \\
\hline Protein $(\mathrm{g})$ & 2.4 & 1.7 & 37.7 \\
\hline $\mathrm{CHO}(\mathrm{g})$ & 16.5 & 72.8 & 38.0 \\
\hline Fat $(g)$ & 0.3 & 0.0 & 0.2 \\
\hline Protein( $\%$ energy) & 12.3 & 2.3 & 49.6 \\
\hline CHO (\% energy) & 84.3 & 97.6 & 49.9 \\
\hline Fat (\% energy) & 3.4 & 0.1 & 0.5 \\
\hline KJ & 327.3 & 1246.5 & 1258.6 \\
\hline $\mathrm{ED}(\mathrm{KJ} / \mathrm{g})$ & 1.09 & 3.89 & 3.84 \\
\hline Weight $/ 300 \mathrm{ml}$ & 306 & 322.5 & 328 \\
\hline
\end{tabular}


Table 2. Mean $( \pm$ SEM) total intake $(\mathrm{KJ})$ at the test meal in the three preload conditions at both preload delays.

\begin{tabular}{l|lllll}
\hline $\begin{array}{l}\text { Preload } \\
\text { Delay }\end{array}$ & Energy (KJ) & Control & CHO enriched & Protein enriched & Combined preloads \\
\hline $120 \mathrm{mins}$ & Total & $5449.48 \pm 242.67$ & $6689.91 \pm 274.86$ & $6243.35 \pm 249.26$ & $6127.58 \pm 229.38$ \\
& Test meal & $3415.91 \pm 242.67$ & $3737.16 \pm 274.86$ & $3265.94 \pm 249.26$ & $3473.00 \pm 229.38$ \\
$30 \mathrm{mins}$ & Total & $5554.63 \pm 255.57$ & $6391.24 \pm 268.59$ & $6179.43 \pm 256.13$ & $6041.77 \pm 249.97$ \\
& Test meal & $3521.07 \pm 255.57$ & $3438.45 \pm 268.58$ & $3202.03 \pm 256.13$ & $3387.20 \pm 249.97$ \\
\multirow{3}{*}{ Combined } & Total & $5502.05 \pm 232.27^{\mathrm{a}^{*}}$ & $6540.58 \pm 261.99^{\mathrm{b}^{*}}$ & $6211.39 \pm 245.99^{\mathrm{c}^{*}}$ & \\
& Test meal & $3468.49 \pm 232.27^{\mathrm{a}}$ & $3587.82 \pm 261.99^{\mathrm{a}}$ & $3233.98 \pm 245.99^{\mathrm{b}}$ & \\
& & & & & \\
\hline
\end{tabular}

Total $=$ breakfast + preload + placebo + test meal

NB- different alphabetic superscripts denote significant difference $(p<0.05 ; * p<0.0005)$. 
Table 3: Mean ( \pm SEM) components of the best-fit quadratic functions of appetite by intake in each condition.

\begin{tabular}{l|lllccc}
\hline & Y-intercept & Linear coefficient & Quadratic coefficient & Y-intercept & Linear coefficient & Quadratic coefficient \\
& & & & & \\
\hline Control & $388.1 \pm 13.0$ & $-0.086 \pm 0.092$ & $-0.000514 \pm 0.000132$ & $105.3 \pm 14.3$ & $0.192 \pm 0.077$ & $0.000373 \pm 0.000112$ \\
Control 120mins & $392.2 \pm 12.9$ & $-0.037 \pm 0.123$ & $-0.000696 \pm 0.00020$ & $95.9 \pm 14.5$ & $0.165 \pm 0.107$ & $0.000471 \pm 0.000168$ \\
Control 30 mins & $383.9 \pm 19.7$ & $-0.136 \pm 0.085$ & $-0.000406 \pm 0.000111$ & $114.6 \pm 23.2$ & $0.219 \pm 0.081$ & $0.000275 \pm 0.000119$ \\
CHO & $392.1 \pm 18.6$ & $-0.133 \pm 0.085$ & $-0.000476 \pm 0.000142$ & $105.8 \pm 21.3$ & $0.242 \pm 0.082$ & $0.000330 \pm 0.000134$ \\
CHO 120 mins & $385.5 \pm 22.9$ & $-0.140 \pm 0.088$ & $-0.000357 \pm 0.000124$ & $107.6 \pm 26.1$ & $0.239 \pm 0.092$ & $0.000252 \pm 0.000113$ \\
CHO 30 mins & $398.8 \pm 18.0$ & $-0.126 \pm 0.110$ & $-0.000595 \pm 0.000204$ & $103.9 \pm 20.3$ & $0.245 \pm 0.090$ & $0.000407 \pm 0.000175$ \\
Protein & $358.4 \pm 20.3$ & $-0.014 \pm 0.076$ & $-0.000609 \pm 0.000138$ & $144.5 \pm 26.6$ & $0.167 \pm 0.083$ & $0.000406 \pm 0.000169$ \\
Protein 120 mins & $361.6 \pm 26.9$ & $-0.049 \pm 0.080$ & $-0.000541 \pm 0.000135$ & $144.1 \pm 30.0$ & $0.205 \pm 0.108$ & $0.000228 \pm 0.000194$ \\
Protein 30 mins & $355.3 \pm 21.3$ & $0.020 \pm 0.110$ & $-0.000676 \pm 0.000205$ & $144.9 \pm 25.0$ & $0.128 \pm 0.097$ & $0.000585 \pm 0.000238$ \\
120 mins & $379.8 \pm 16.1$ & $-0.075 \pm 0.076$ & $-0.000531 \pm 0.000125$ & $115.0 \pm 18.5$ & $0.203 \pm 0.170$ & $0.0003174 \pm 0.000105$ \\
30 mins & $379.4 \pm 16.9$ & $-0.086 \pm 0.081$ & $-0.000560 \pm 0.000139$ & $121.15 \pm 20.7$ & $0.198 \pm 0.075$ & $0.0004226 \pm 0.000151$ \\
\hline
\end{tabular}


Table 4: Mean $( \pm \mathrm{SEM})$ maximum hunger and minimum fullness ratings over the course of the test meal.

\begin{tabular}{l|ll}
\hline & $\begin{array}{l}\text { Maximum hunger during } \\
\text { pasta meal }\end{array}$ & $\begin{array}{l}\text { Minimum fullness during } \\
\text { pasta meal }\end{array}$ \\
\hline Control & $411.8 \pm 13.0$ & $78.8 \pm 13.1$ \\
Control 120mins & $409.7 \pm 11.6$ & $113.6 \pm 21.8$ \\
Control 30 mins & $410.7 \pm 9.2$ & $96.2 \pm 14.3$ \\
CHO & $397.6 \pm 21.9$ & $94.8 \pm 21.2$ \\
CHO 120 mins & $420.4 \pm 13.3$ & $91.3 \pm 19.5$ \\
CHO 30 mins & $409.5 \pm 16.7$ & $93.0 \pm 19.6$ \\
Protein & $381.5 \pm 25.3$ & $121.6 \pm 26.5$ \\
Protein 120 mins & $375.4 \pm 19.1$ & $117.6 \pm 20.0$ \\
Protein 30 mins & $378.5 \pm 19.1$ & $119.6 \pm 21.5$ \\
120 mins & $397.0 \pm 16.7$ & $98.4 \pm 17.1$ \\
30 mins & $401.8 \pm 12.2$ & $107.5 \pm 19.2$ \\
\hline
\end{tabular}


Figure Legends

Figure 1: Intake (g) during ad libitum lunch following three beverages served 120 minutes ( $\square$ ) and 30 minutes $(\boldsymbol{\square})$ prior.

Figure 2: Total intake (KJ) at two preload time intervals comprising ad libitum lunch ( $\square$ ) and preload \& breakfast

Figure 3: VAS ratings throughout the morning across preload conditions: control (O), CHOenriched ( $\bigcirc$ ) and protein enriched ( $\square$ ) beverages at Delay 120 (_) and Delay 30 (----) for hunger (3a) and fullness (3b).

Figure 4: Mean best fit quadratic functions of intake (g) plotted against hunger (a) and fullness (b) during an ad libitum lunch following control ( $\bigcirc$ ), CHO enriched ( $\bigcirc$ ) and protein enriched ( $\square$ ) beverages. 


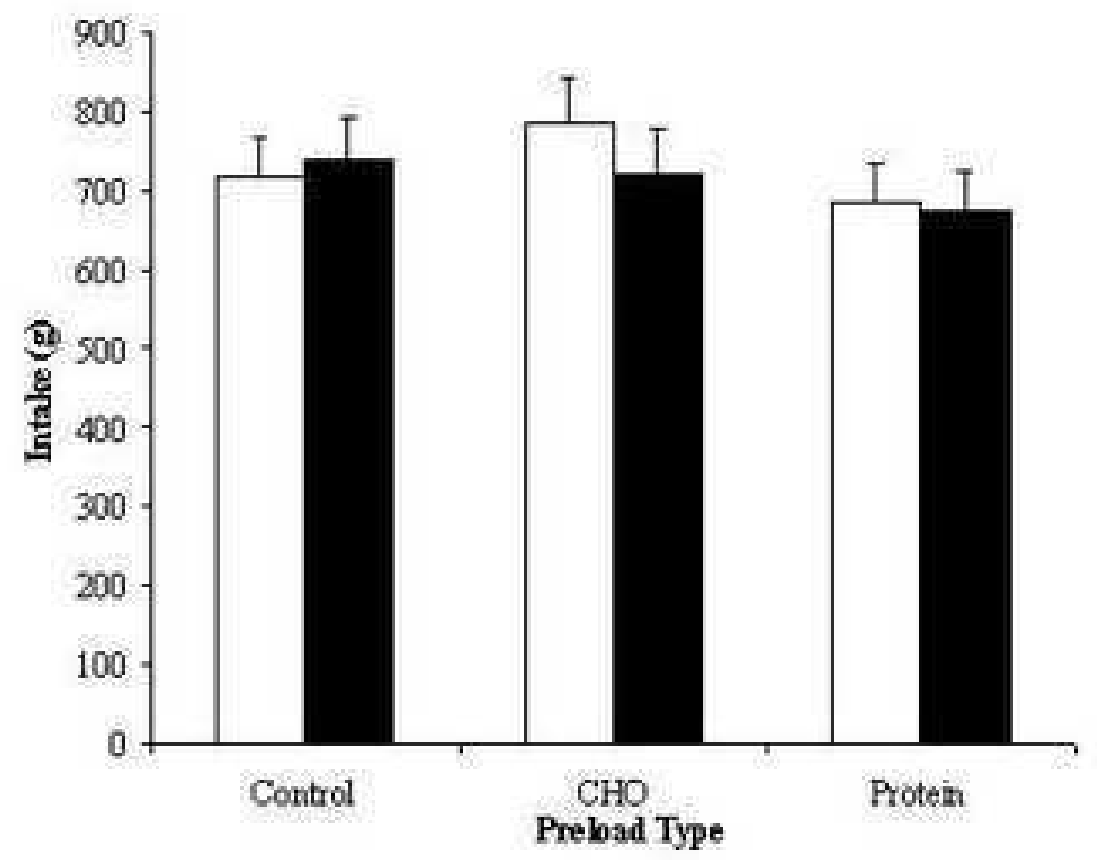




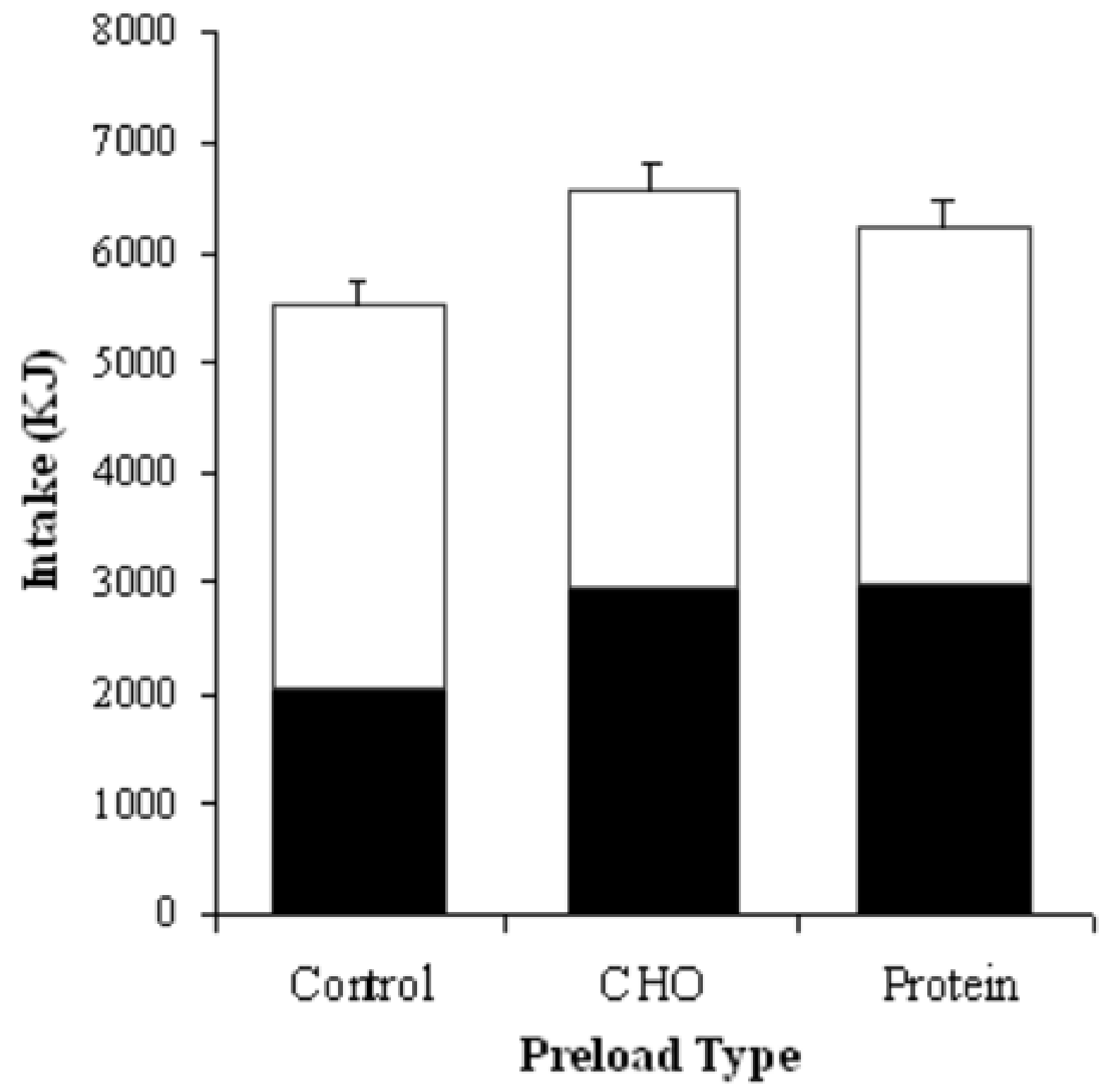




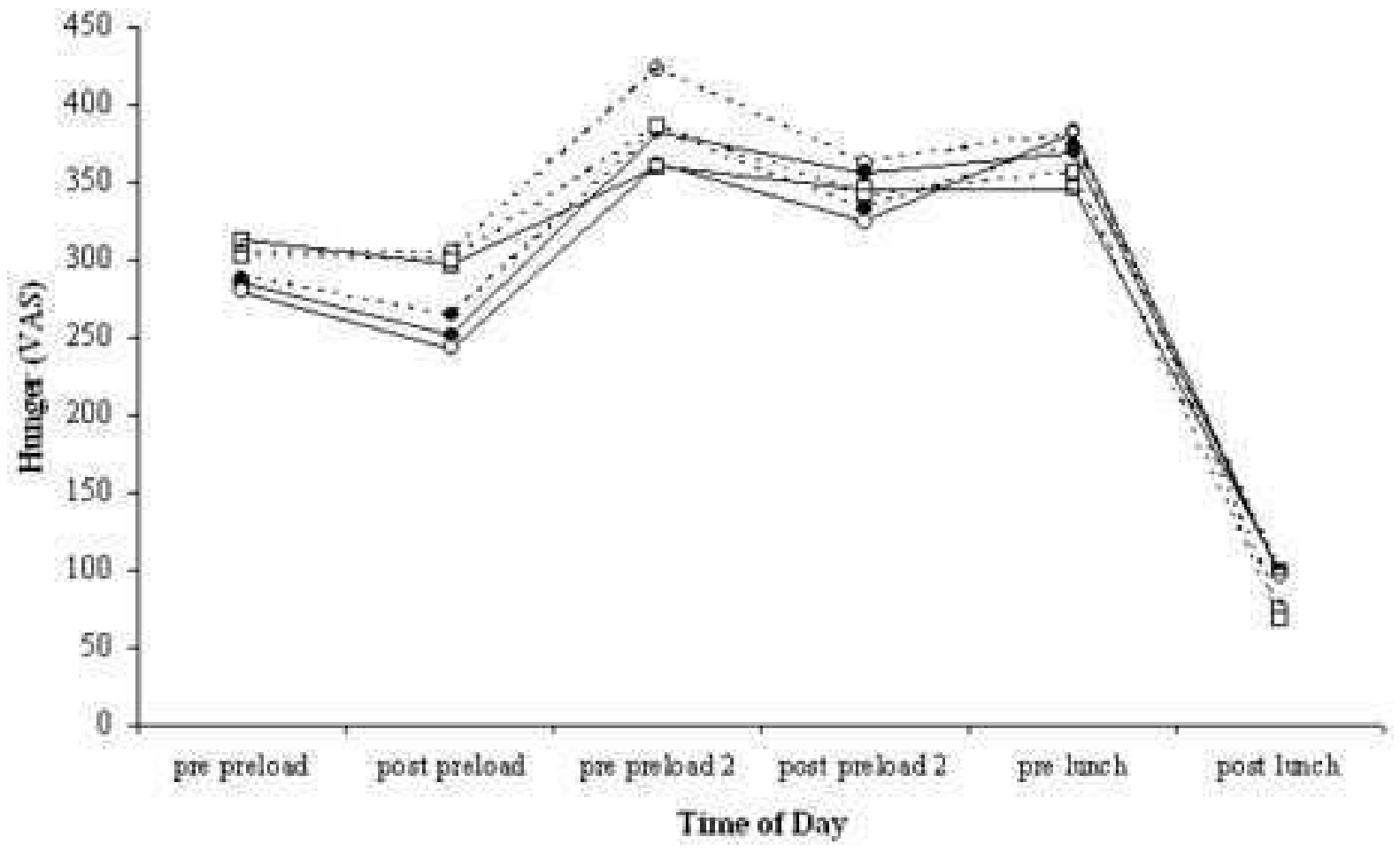




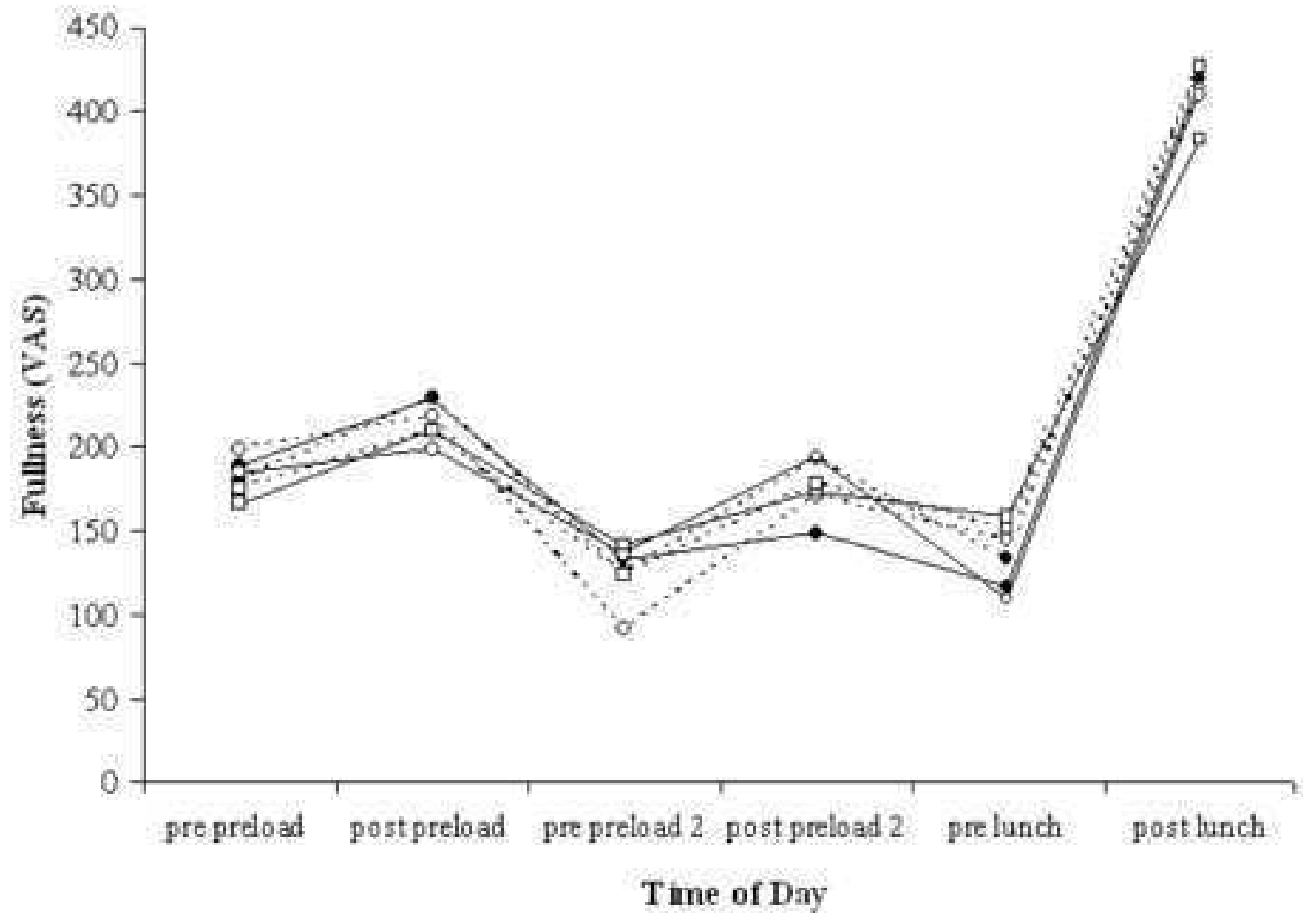




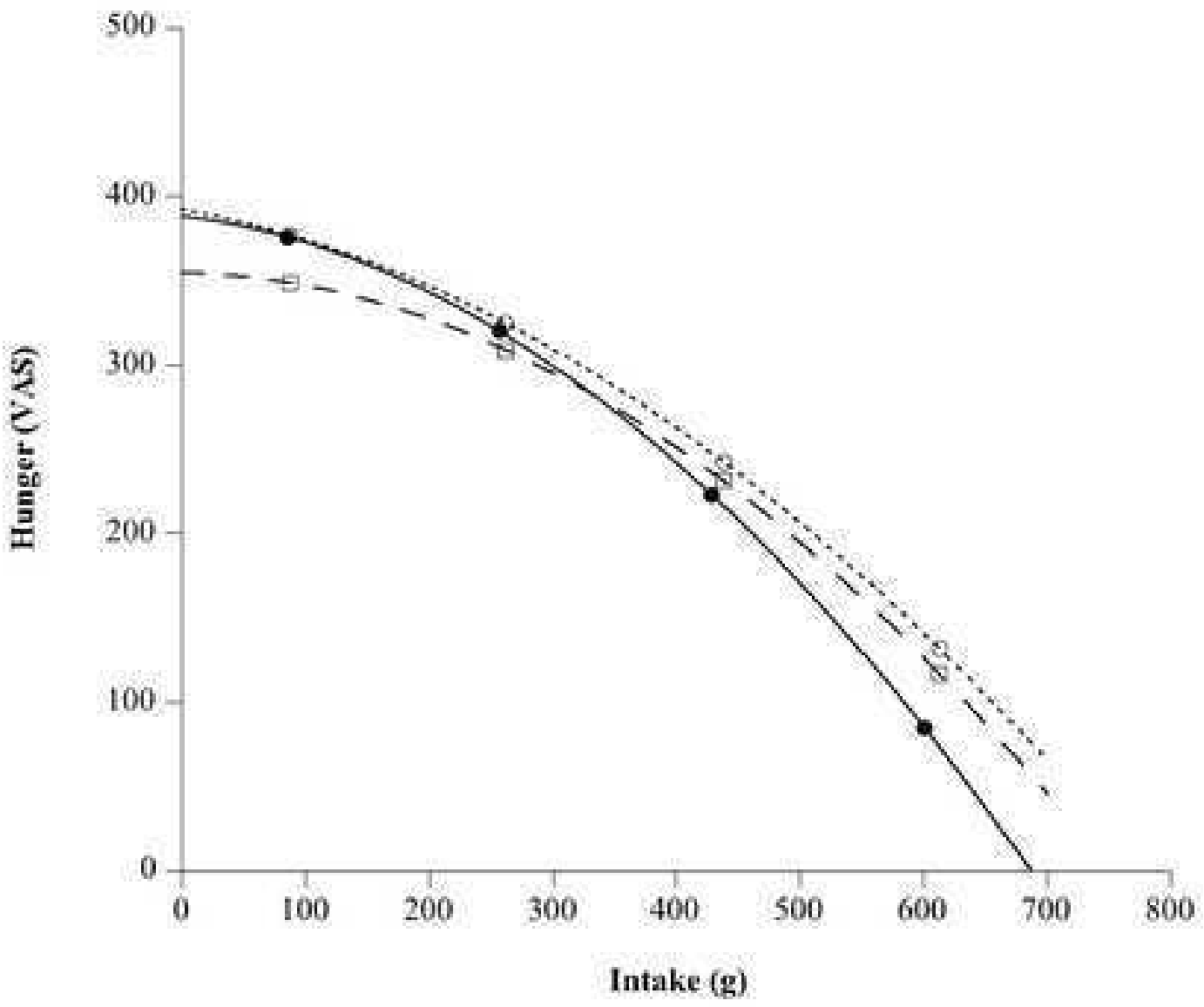




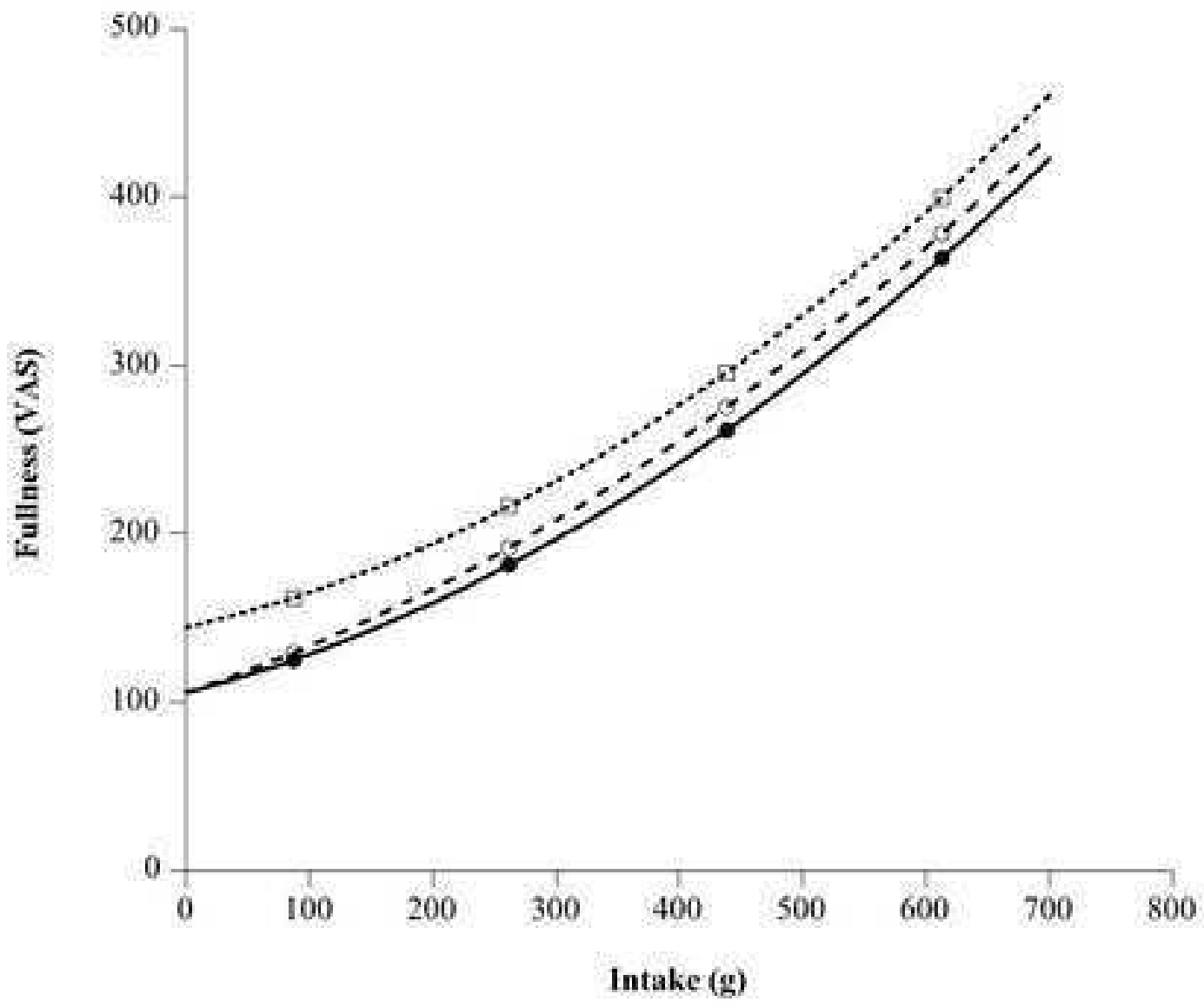

